\title{
DISTRIBUTION OF PDGFR $\alpha+$ CELLS AND INTERSTITIAL CELLS OF CAJAL IN THE HUMAN FETAL GUT
}

\author{
Goran Radenković1, Aleksandra Veličkov ${ }^{1}$, Vladimir Petrović ${ }^{1}$, Miloš Dičić ${ }^{2}$, Marko Gmijović3
}

\begin{abstract}
Two types of interstitial cells, interstitial cells of Cajal (ICC) and "fibroblast-like" cells, recently named platelet-derived growth factors receptor positive (PDGFR $\alpha+$ ) cells, are present within the muscular layer of gastrointestinal (GI) tract. ICC and PDGFR $\alpha+$ cells represent different classes of cells with unique ultrastructure, molecular phenotype and function, and they occupy the same anatomical niches in the GI tract. It is considered that PDGFR $\alpha+$ cells such as ICC, mediate enteric inhibitory neurotransmission. Platelet-derived growth factors (PDGFs) are major mitogens for many cell types of mesenchymal origin, like fibroblasts and smooth muscle cells, and during embryogenesis, PDGF signaling is important in organogenesis. In the available literature, there is no data on the presence and distribution of PDGFR $\alpha$ immunoreactive cells in the human intestine during fetal period.

The aim of this study was to identify PDGFR $\alpha$ immunoreactive cells in the gut of human fetuses, as well as to determine their distribution in relation to smooth muscle cells, ICC and enteric nerve structures.

The material consisted of 12 Human Fetuses, gestational age from 10 to 12 weeks. The immunohistochemical test was carried out with the PDGFR- $\alpha$ antibody, ICC were identified using the C-kit antibody, while the muscle structures were demonstrated by the Desmin antibody.

During the development of the human intestine, at week 11, PDGFR $\alpha$ immunoreactive cells are present within the circular muscle layer, while they are absent in the myenteric plexus region and in the parts below the serosa. Unlike them, ICC are present only around the inception of the myenteric plexus ganglia.

In the fetal period of the human development, PDGFR $\alpha$ immunoreactive cells are present in all parts of the intestines, they are localized within the circular muscle layer and do not coincide with the ICC.
\end{abstract}

Acta Medica Medianae 2020;59(1):51-59.

Key words: PDGFR $\alpha$, C-kit, interstitial cells of Cajal, fetal gastrointestinal tract

\author{
${ }^{1}$ University of Niš, Faculty of Medicine, Department of Histology \\ and Embryology, Niš, Serbia \\ 2University of Niš, Faculty of Medicine, Niš, Serbia \\ ${ }^{3}$ Clinic for Digestive Surgery, Clinical Center Niš, Niš, Serbia
}

Contact: Goran Radenković

81 Dr Zoran Djindjic Blvd., 18000 Niš, Serbia

E-mail: goran.radenkovic@medfak.ni.ac.rs

\section{Introduction}

The muscular layer of the gastrointestinal (GI) tract is a complex tissue that, in addition to smooth muscle cells, contains a variety of cellular phenotypes. Within the muscular layer of GI tract, there are at least two types of interstitial cells, interstitial cells of Cajal (ICC) and cells called "fibroblast-like" or "ICC-like cells" $(1,2)$. These interstitial cells of mesenchymal origin form gap junctions with each other and with surrounding smooth muscles thus conducting electrical signal and regulating muscle excitability (3). Interstitial cells of Cajal express c-kit (4), so immunohistochemical labeling of the Kit receptor has enabled the reliable identification and study of ICC function and pathophysiology (5) on human and animal material.

The studies of ICC development suggest that some types of ICC and smooth muscle cells have a common precursor that expresses the c-kit (6). Kit signaling is thought to be necessary for the separation of mesenchymal precursors during differentiatition toward ICC or smooth muscle cells, for maintaining the ICC phenotype, and for normal postnatal development (7). The pacemaker role of the ICC around the myenteric plexus (ICC-MY), which spontaneously generate slow waves necessary for peristaltic contraction, has recently been confirmed (3, 8 ). The ICC within the muscle layer (intramuscular ICC - ICC-IM) have a role as mediators of 
cholinergic and nitrinergic neurotransmission (9-11), participate in afferent signaling and integration of sensory-motor function as an element of the afferent branch of the gastrointestinal reflex (12). ICC also have a sensory role in the transduction of mechanical stimuli, that is, they function as stretch receptors (13). Loss and dysfunction of ICC have been demonstrated in numerous motility disorders (14-18). Contrary to the studies of ICC, the study of "fibroblast-like" cells has only recently been made possible by immunohistochemical labeling of platelet derived growth factor receptor A (PDGFR $\alpha$ ) (19). These cells are different from ICC, but they occupy the same anatomical niches in the GI tract in mice, primates, and humans (19-24). ICC and PDGFR $\alpha+$ cells represent different classes of cells with unique ultrastructure, molecular phenotype and function. Smooth muscle cells are electrically connected to ICC and PDGFR $\alpha+$ cells via gap junctions and form an integrated unit - smooth muscle cell, ICC and PDGFR $\alpha+$ cells (SIP) syncytium (3). SIP cells express different receptors and ion channels, and changes in conductivity in any type of SIP cell affect the excitability and reactions of the syncytium. Interstitial cells are also found in various other smooth muscle organs; however, in most cases the physiological and pathophysiological role of these cells is not clearly defined $(25,26)$.

PDGFR $\alpha+$ cells are also closely related to the motor neurons varices and are intertwined with ICC around neural processes $(19,27)$. Immunohistochemical studies have shown that PDGFRa+ cells in the musculature of the GI tract express small conductance $\mathrm{Ca}^{2+}$-activated $\mathrm{K}^{+}\left(\mathrm{SK}_{3}\right)$ channels, and mediate enteric inhibitory responses to purines in GI muscles (28-30). This observation, together with the findings that PDGFR $\alpha+$ cells are very closely related to enteric motor neurons and electrically paired with smooth muscle cells (31), suggests that they, such as ICC, may mediate enteric inhibitory neurotransmission. Major mitogens for many cell types of mesenchymal origin, like fibroblasts and smooth muscle cells, are platelet-derived growth factors (PDGFs) (32). During embryogenesis, PDGF signaling is important in organogenesis (33), while adult cells of multiple organs expressing PDGF ligands and receptors often play an important role in the pathophysiology of various disorders, including GI dysmotility (34).

In the available literature, there is no data on the presence and distribution of PDGFR $\alpha$ immunoreactive cells in the human intestine during fetal period.

\section{Aim}

The aim of this study was to identify PDGFR $\alpha$ immunoreactive cells in the gut of human fetuses, as well as to determine their distribution in relation to smooth muscle cells, ICC and enteric nerve structures.

\section{Materials and methods}

Material

The material consisted of 12 human fetuses, in the gestational age from 10 to 12 weeks. The tissue material was obtained from the Institute of Pathology, Clinical Center Niš, after legal abortions and premature births due to prepartal deaths. Gestational ages were estimated by anatomical criteria according to the crown-rump length, biparietal diameter, and foot length, as well as from the anamnestic data on pregnancy age. There were no gastrointestinal disorders in the specimens, and both sexes were represented in the sample. A macroscopic examination was performed in detail and only specimens that did not undergo post-mortem changes were selected. The study was approved by the Ethics Committee of the University of Niš Faculty of Medicine, and was performed within the internal project no. 22 of the University of Niš Faculty of Medicine.

\section{Tissue preparation}

Gut specimens were isolated and fixed in formaldehyde $(10 \%)$, paraffin embedded, sequentially sectioned at $4 \mu \mathrm{m}$, and routinely H\&E stained due to histological examination.

\section{Immunohistochemistry}

The specimens were exposed to PDGFR $\alpha$ antibodies, anti-c-kit antibodies to investigate ICC, and smooth muscle cells were immunohistochemically labeled with anti-desmin (DES) antibodies. Section deparaffinization was performed in xylol and descending series of alcohol rinses (less than $1 \mathrm{~min}$ each) followed by rehydration in distilled water. The tissue sections were incubated after blocking endogenous peroxidase $\left(3 \% \mathrm{H}_{2} \mathrm{O}_{2}\right.$ for $10 \mathrm{~min}$ at room temperature) with the primary antibody in a humidified chamber at room temperature for one hour, followed by rinses in a phosphate-buffered solution (0.1 M PBS, pH 7.4). The primary antibodies were dissolved in Dako antibody diluent (EnVisionTM FLEX DM830 Code: K8006, Dako, Denmark). After secondary antibody administration (EnVisionTM FLEX SM802, Code: K8000, Dako, Denmark) for 45 min at room temperature, immune complexes were visualized by the Daco REAL EnVisionTM Detection System, Code: k5007 (Dako, Denmark). Mayer's haematoxylin was used for counterstaining of all immunolabeled sections, and immunoreactivity was absent in negative controls in which the primary antibody was omitted. The primary antibodies used in the research and their respective dilutions are listed in Table 1. 
Table 1. Antibodies

\begin{tabular}{||cccc|}
\hline Antigen & Clone & Supplier & Dilution \\
\hline \hline C-kit & CD-117 & Dako & $1: 300$ \\
PDGFR $\alpha$ & Polyclonal & Abcam & $1: 50$ \\
Desmin & DE-R-11 & Dako & $1: 100$ \\
\hline
\end{tabular}

\section{Results}

During the development of the human intestine, at week 11 , immunoreactivity to desmin is present in all parts of the gut tissue. Desmin immunoreactivity is present in all parts of the intestine in the form of a concentric band of cells (Figure 1), which by their localization correspond to the circular muscle layer, while the longitudinal layer is not yet differentiated. Only in the terminal portions of the foregut and initial portions of the midgut are individual desmin immunopositive cells localized immediately below the serosa, representing the origin of the longitudinal muscle layer.

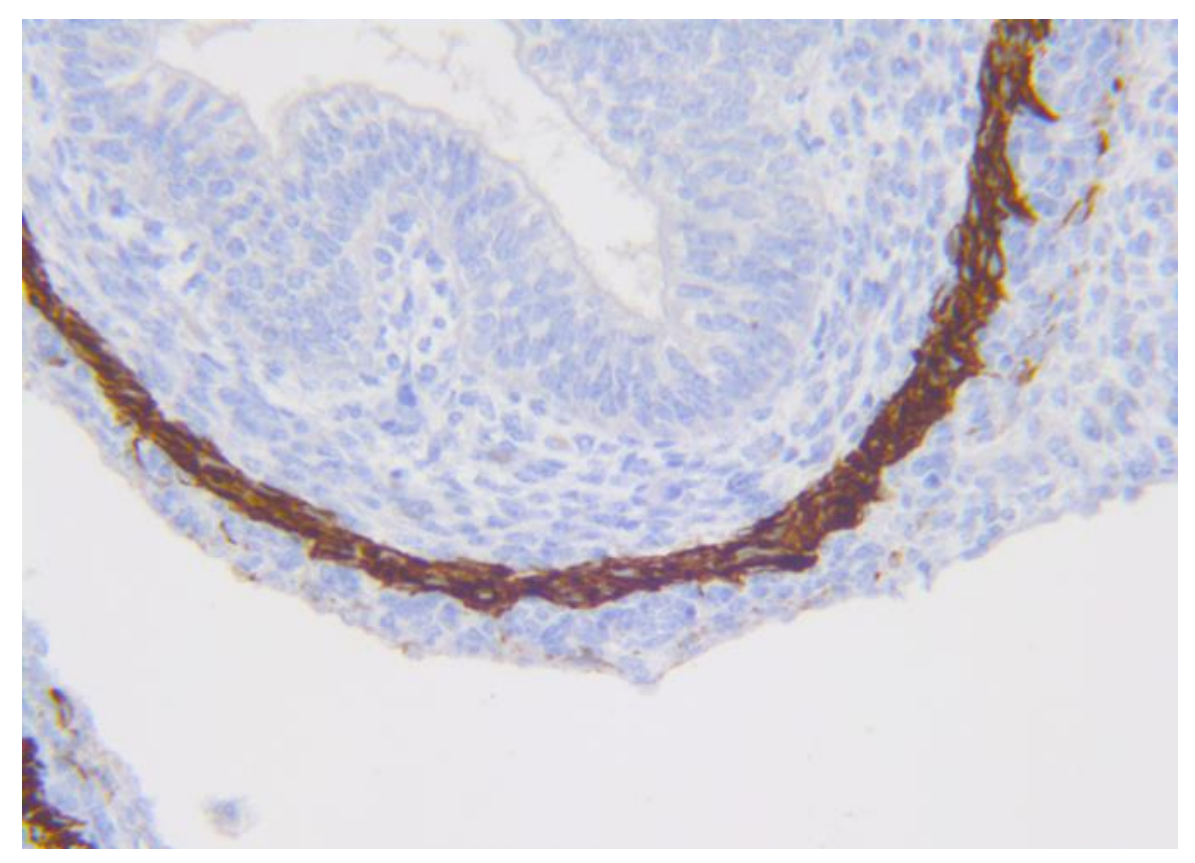

Figure 1. Desmin immunoreactive cells (dark brown stained) are present in the form of a concentric band and correspond to the circular muscle layer. Desmin immunohistochemistry, x200

PDGFR $\alpha$ immunoreactivity is present in all parts of the human primitive gut (Figure 2) at week 11. PDGFR $\alpha$ immunoreactive cells are present within the circular muscle layer, while they are not present in the myenteric plexus (MP) region, or in the parts below the serosa. PDGFR $\alpha+$ cells are elongated, spindle-shaped cells, oriented in parallel to the longitudinal axis of the smooth muscle cells within the circular gut muscle layer. In the submucosal region, there are two PDGFR $\alpha$ low immunoreactive cells (Figure 2 arrowhead).

In week 11 of human development, c-kit immunoreactive cells are present in all parts of the gut in the MP region, as continuous rows and nets of cells present around the MP ganglia, at the outer border of the circular muscle layer (Figure 3). C-kit immunoreactive cells lie at the edges of the inception of the MP ganglia but they are not present within them. They are also absent within the circular muscle layer, as well as in the region below the serosa. In submucosa, in the area where submucosal ganglions develop, c-kit immunoreactivity is also absent. C-kit immunoreactive cells are multipolar with large round or oval nuclei, a small body, and numerous thin processes. Their processes form a network around the MP ganglia. In addition to ICC, a large number of c-kit immunoreactive mast cells are present, but they are easily distinguished from ICC on the basis of their shape and granular content. 


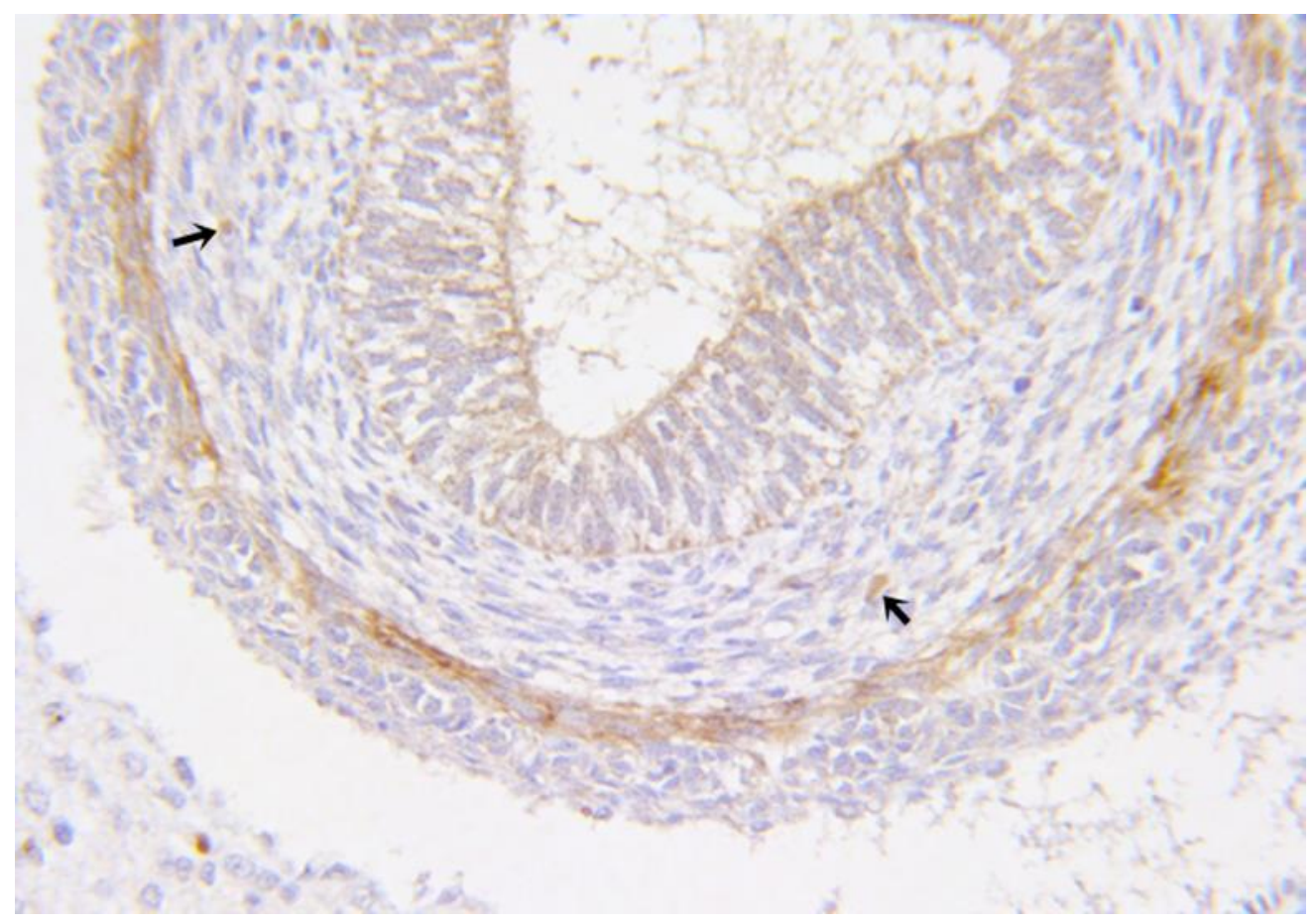

Figure 2. The distal portion of the midgut at $11^{\text {th }}$ week of fetal development. PDGFRa immunoreactive cells (dark brown stained) are present within the circular muscle layer. Two PDGFR $\alpha$ low immunoreactive cells in the submucosal region (arrowhead). PDGFR $\alpha$ immunohistochemistry, $\times 200$

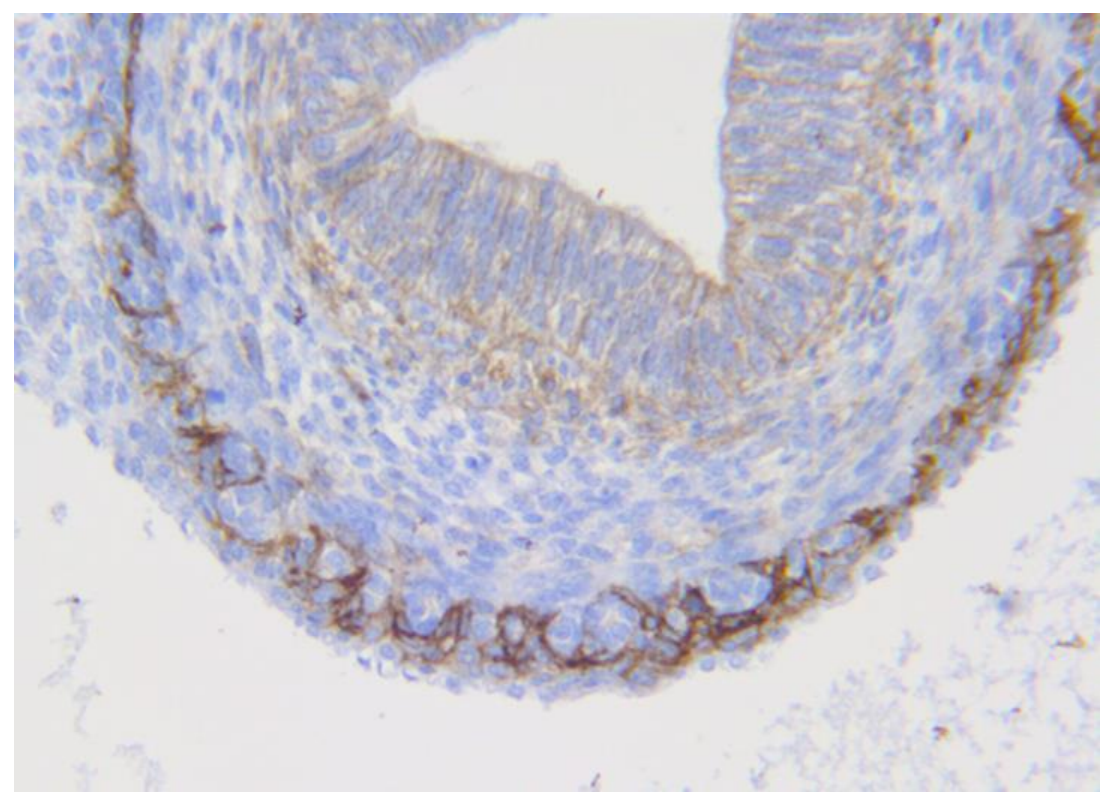

Figure 3. The distal portion of the midgut at $11^{\text {th }}$ week of fetal development. C-kit immunoreactive cells (dark brown stained) are present in the MP region and clearly limit the onset of the MP ganglia (arrows). C-kit immunohistochemistry, x200 
The comparison of desmin, C-kit and PDGFRa immunoreactivity in the distal midgut clearly shows that the localization of C-kit and PDGFR $\alpha$ immunoreactive cells is significantly different (Figure 4).

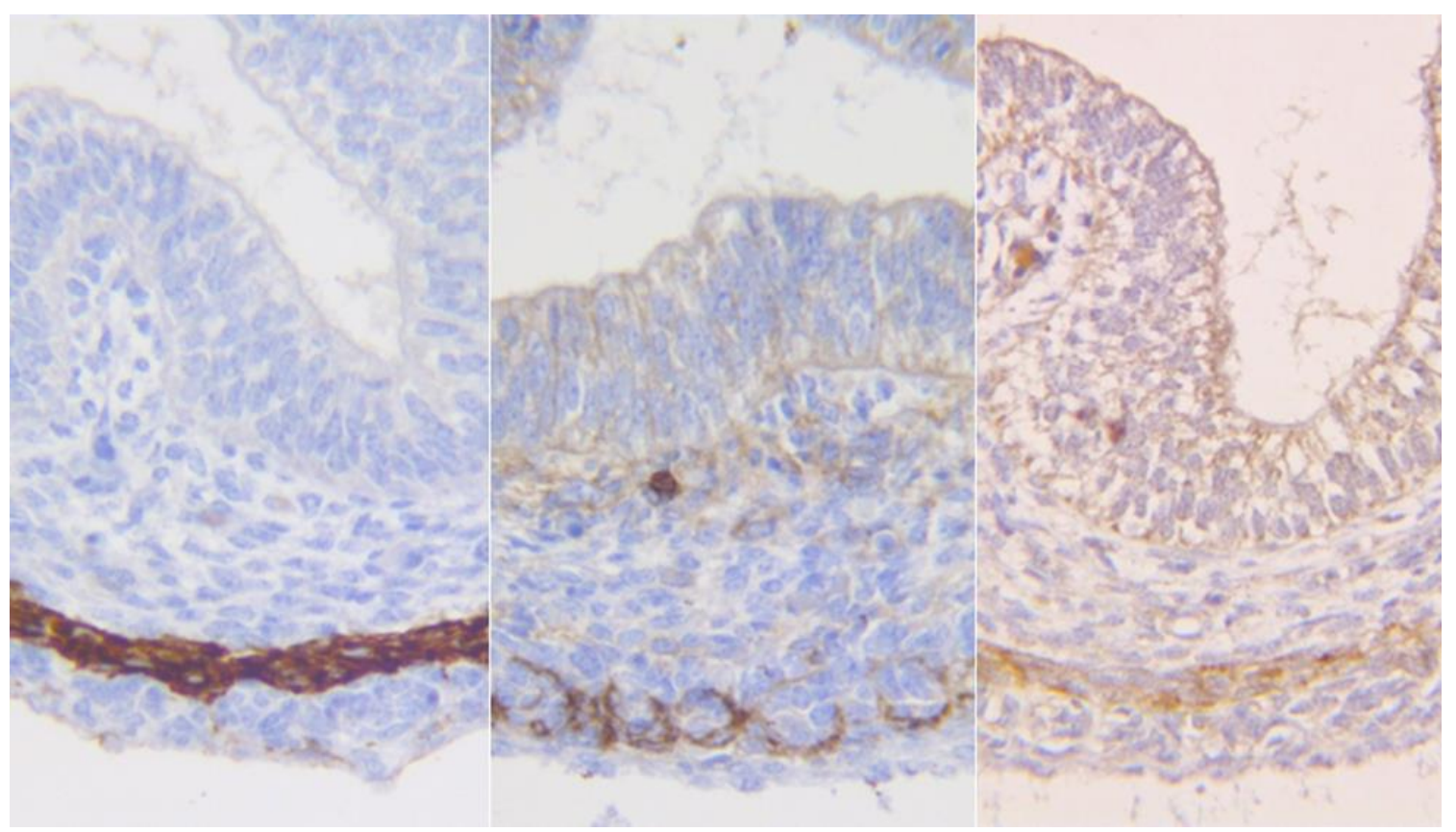

Figure 4. Comparison of desmin, C-kit and PDGFRa immunoreactivity in the distal midgut at $11^{\text {th }}$ week of fetal development. PDGFR $\alpha$ immunoreactive cells are present only within the circular muscle layer, while ICGs do not exhibit PDGFR $\alpha$ immunoreactivity. x200

\section{Discussion}

Based on the desmin immunohistochemistry results of our research, we can observe that in all parts of the fetal intestine, the circular muscular layer develops first, and only later the longitudinal layer, following the principle of proximal-distal gradient. These results are consistent with the previous studies $(35,36)$. During $11^{\text {th }}$ and $12^{\text {th }}$ week of development, C-kit immunopositive cells, which correspond to ICC, are present in all parts of the human fetal intestine in the MP region and are surrounding the inception of the MP ganglia, but they are absent within the circular muscle layer. This finding is also consistent with the results of previous studies, which indicate that intramuscular ICC develop only in the late fetal period, while certain ICC subtypes develop after birth (37-39).

Platelet derived growth factor (PDGF) is a major mitogen for many cells of mesenchymal origin, including fibroblasts and smooth muscle cells, which is why PDGF signaling is especially important during embryogenesis $(34,40)$. PDGF receptor A (PDGFR $\alpha$ ) is a receptor present on the surface of a large number of cell types, which binds one of the PDGF isoforms, causing cellular growth and differentiation during organ development and is responsible for the normal functioning of tissues and organs (41,
42). Previously considered mainly a developmental growth factor receptor in the GI tract, the discovery of receptor tyrosine kinase PDGFR $\alpha$ expression in "fibroblast-like" cells within tunica muscularis (19) has opened the door to new trials and definitions of the role of these cells $(23,27)$. The most significant finding of our study is that PDGFR $\alpha$ immunoreactive cells are present in all parts of the human intestine in the early fetal development period. These cells are localized within the circular muscle layer, on the contrary, no PDGFR $\alpha+$ cells have been observed in the MP region as well as in parts just below the serosa. An identical localization of PDGFR $\alpha$ immunoreactive cells also exists in the gut of adults, with the difference that they are also present in the MP region in adults, where they form three-dimensional networks. This position of PDGFR $\alpha$ immunoreactive cells is consistent with the fact about their possible role in neurotransmission of signaling from ICC to smooth muscle cells $(23,43)$. It has been previously reported that PDGFR $\alpha+$ cells have important roles in the morphogenesis of small intestinal mucosa villus of the mouse $(44,45)$. PDGFR $\alpha+$ cells were also found in the subepithelial layer of the adult guinea pig GI tract (46). However, the details of the distribution and functions of PDGFR $\alpha+$ cells in fetus GI tract have not been reported. 
Kurahashi et al. have described a specific type of PDGFR $\alpha+$ cells in the lamina propria of the human GI tract (47), and suggested that subepithelial PDGFR $\alpha+$ cells have a role in sensory and secretomotor signaling, proliferation, differentiation, and apoptosis of epithelial cells, and in epithelial cellular pathology, including inflammatory responses and tumorigenesis. Subepithelial PDGFR $\alpha+$ cells in adults form a sheath just beneath the epithelium and cover the crypts from their base to the luminal surface of the epithelium. It is suggested that these cells may have modulatory functions in immune and sensory responses and in the maintenance of mucosal homeostasis, but the roles of these cells in physiological and pathophysiological processes are still unknown. In our research, there was a low PDGFR $\alpha$ submucosal immunoreactivity during the early period of fetal development, and dominant PDGFR $\alpha$ were present within the circular muscle layer. As already mentioned, due to their close contact with enteric nerve endings and smooth muscle cells within the circular muscle layer, it is assumed that these cells primarily play a role in the neuromodulation of peristalsis.

Another important result of our study is that PDGFR $\alpha$ cells differ from ICC and that they are functionally close but still different cell types of interstitial cells. In adults, PDGFR $\alpha$ cells are widely distributed within the MP region and in circular and longitudinal muscle layers throughout the human colon (23). Blair et al. (21) have shown relationships between enteric neurons and interstitial cells in primates. They have shown that PDGFR $\alpha+$ cells are closely associated with ICC and occupy the same anatomical niches as ICC-MY and ICC-IM. However, in contrast to the distribution of intestinal cells in adults, we showed in our study that, in the fetal period, PDGFR $\alpha$ activity was not observed in the ICCMY domains around the ganglia. This finding indicates that PDGFR $\alpha$ cells develop later than the ICC within GI tract. Further, our results show that unlike the region of MP, PDGF cells are present in the circular muscle in the fetal period and there are still no differentiated ICC-IM.

Ultrastructural studies show that enteric neurons do not effectuate any direct contact with smooth muscle cells or synaptic specializations; on the other hand, ICC make close contacts with both cholinergic and nitrinergic neurons, forming synapse-like connections at one end and gap junctions with smooth muscle cells $(3,48)$. Calcium activated chloride channels (Ano1) are highly expressed and exclusively by ICC throughout the GI tract $(21,49)$, so the major excitatory neurotransmitter - acetylcholine induces depolarization by the activation of Ano1 currents (50). ICC-IM also respond to inhibitory neurotransmitters between neurons and smooth muscles (51). PDGFR $\alpha+$ are very similar to ICC-IM in adults, and also form gap junctions with surrounding smooth muscle cells $(3,20,21)$. PDGFR $\alpha+$ cells express guanylate cyclase, purinergic P2Y1 receptors and small conductance $\mathrm{Ca}^{2+}$ - activated $\mathrm{K}^{+}\left(\mathrm{SK}_{3} \mathrm{~K}^{+}\right)$channels $(23,27,52)$ which indicates that PDGFR $\alpha+$ cells mediate enteric inhibitory neurotransmision. It has been confirmed that PDGFR $\alpha+$ cells, like ICC, generate inhibitory post junctional responses in GI muscles (27). Gap junctions provide electrical coupling between cells, such that induction of a $\mathrm{K}^{+}$current in PDGFR $\alpha+$ cells results in hyperpolarization, first of these cells and immediately after that in net hyperpolarization of the SIP syncytium and reduce muscle contraction.

In contrast to our results, PDGFR $\alpha+$ cells in adults form a network adjacent to ICC around the myenteric ganglia (23). ICC-MY have a pacemaker role to generate spontaneous electrical activity, while the function of myenteric PDGFR $\alpha+$ is still unknown. Since they are interconnected with ICC-MP, they may have a role in the propagation and modulation of the electrical peristaltic waves.

At present, little is known about the involvement of PDGFR $\alpha+$ cells in GI motor dysfunction. It is certain that the changes in purinergic neural inputs could have effects on colonic motility. Enhanced activation of PDGFR $\alpha$ in mice, contribute to the development of GI fibrosis and sarcoma (53). In a recent study (54), it has been concluded that colonic transit disorder may be due to the downregulation of the Kit and Ano1 channels and the upregulation of $\mathrm{SK}_{3}$ channels in PDGFR $\alpha+$ cells, suggesting that the imbalance between ICC and PDGFR $\alpha$ distribution might be a possible reason for gut dysmotility. Furthermore, some stromal tumors (GIST) are positive for PDGFR $\alpha(55,56)$, so it is possible that these cells, like ICC, can be malignantly transformed.

\section{Conclusion}

In the fetal period of human development, PDGFR $\alpha$ immunoreactive cells are present in all parts of the intestine, localized within the circular muscle layer, and do not coincide with ICC.

\section{Acknowledgements}

This work was supported by the Ministry of Science and Technological Development of the Republic of Serbia (project 43012) and by the Faculty of Medicine in Niš internal project number 22. 


\section{References}

1. Komuro T, Seki K, Horiguchi K. Ultrastructural characterization of the interstitial cells of Cajal. Archives of histology and cytology 1999;62(4):295-316. [CrossRef] [PubMed]

2. Pieri L, Vannucchi MG, Faussone-Pellegrini MS. Histochemical and ultrastructural characteristics of an interstitial cell type different from ICC and resident in the muscle coat of human gut. Journal of cellular and molecular medicine 2008;12(5B):1944-55.

\section{[CrossRef] [PubMed]}

3. Sanders KM, Ward SM, Koh SD. Interstitial cells: regulators of smooth muscle function. Physiological reviews 2014;94(3):859-907.[CrossRef] [PubMed]

4. Huizinga JD, Chen J-H, Mikkelsen HB, Wang X-Y, Parsons SP, Zhu YF. Interstitial cells of Cajal, from structure to function. Frontiers in Neuroscience 2013; 7:43.[CrossRef] [PubMed]

5. Ward SM, Burns AJ, Torihashi S, Sanders KM. Mutation of the proto-oncogene c-kit blocks development of interstitial cells and electrical rhythmicity in murine intestine. The Journal of physiology 1994;480 (Pt 1):91-7.[CrossRef] [PubMed]

6. Kluppel M, Huizinga JD, Malysz J, Bernstein A. Developmental origin and Kit-dependent development of the interstitial cells of cajal in the mammalian small intestine. Developmental dynamics : an official publication of the American Association of Anatomists 1998;211(1):60-71.[CrossRef]

7. Beckett EA, Ro S, Bayguinov Y, Sanders KM, Ward SM. Kit signaling is essential for development and maintenance of interstitial cells of Cajal and electrical rhythmicity in the embryonic gastrointestinal tract. Developmental dynamics: an official publication of the American Association of Anatomists 2007;236(1):6072.[CrossRef] [PubMed]

8. Takaki M. Gut pacemaker cells: the interstitial cells of Cajal (ICC). Journal of smooth muscle research = Nihon Heikatsukin Gakkai kikanshi 2003;39(5):13761.[CrossRef] [PubMed]

9. Iino S, Ward SM, Sanders KM. Interstitial cells of Cajal are functionally innervated by excitatory motor neurones in the murine intestine. The Journal of physiology 2004;556(Pt 2):521-30.[CrossRef] [PubMed]

10. Ward SM, McLaren G], Sanders KM. Interstitial cells of Cajal in the deep muscular plexus mediate enteric motor neurotransmission in the mouse small intestine. The Journal of physiology 2006;573(Pt 1): 147-59. [CrossRef] [PubMed]

11. Kito $Y$. The functional role of intramuscular interstitial cells of Cajal in the stomach. Journal of smooth muscle research $=$ Nihon Heikatsukin Gakkai kikanshi 2011;47(2):47-53.[CrossRef] [PubMed]

12. Huizinga JD, Reed DE, Berezin I, Wang XY, Valdez DT, Liu LW, et al. Survival dependency of intramuscular ICC on vagal afferent nerves in the cat esophagus. American journal of physiology Regulatory, integrative and comparative physiology 2008;294(2):R302-10. [CrossRef] [PubMed]

13. Powley TL, Wang XY, Fox EA, Phillips RJ, Liu LW, Huizinga JD. Ultrastructural evidence for communication between intramuscular vagal mechanoreceptors and interstitial cells of Cajal in the rat fundus. Neurogastroenterology and motility: the official journal of the European Gastrointestinal Motility Society 2008;20 (1):69-79.[CrossRef] [PubMed]
14. Faussone-Pellegrini MS, Cortesini C. The muscle coat of the lower esophageal sphincter in patients with achalasia and hypertensive sphincter. An electron microscopic study. Journal of submicroscopic cytology 1985;17(4):673-85.[CrossRef] [PubMed]

15. Vanderwinden JM, Rumessen JJ. Interstitial cells of Cajal in human gut and gastrointestinal disease. Microscopy research and technique 1999;47(5):344-60. [CrossRef] [PubMed]

16. Zarate N, Mearin F, Wang XY, Hewlett B, Huizinga JD, Malagelada JR. Severe idiopathic gastroparesis due to neuronal and interstitial cells of Cajal degeneration: pathological findings and management. Gut 2003;52 (7):966-70.[CrossRef] [PubMed]

17. Gockel I, Bohl JR, Eckardt VF, Junginger T. Reduction of interstitial cells of Cajal (ICC) associated with neuronal nitric oxide synthase (n-NOS) in patients with achalasia. The American journal of gastroenterology 2008;103(4):856-64.[CrossRef] [PubMed]

18. Velickov A, Mitrovic O, Djordjevic B, Sokolovic D, Zivkovic V, Velickov A, et al. The effect of bilberries on diabetes-related alterations of interstitial cells of Cajal in the lower oesophageal sphincter in rats. Histology and histopathology 2016:11829. [CrossRef] [PubMed]

19. Iino S, Horiguchi K, Horiguchi S, Nojyo Y. C-Kitnegative fibroblast-like cells express platelet-derived growth factor receptor alpha in the murine gastrointestinal musculature. Histochemistry and cell biology 2009;131(6):691-702.[CrossRef] [PubMed]

20. Grover M, Bernard CE, Pasricha PJ, Parkman HP, Abell $T L$, Nguyen LA, et al. Platelet-derived growth factor receptor alpha (PDGFRalpha)-expressing "fibroblastlike cells" in diabetic and idiopathic gastroparesis of humans. Neurogastroenterology and motility: the official journal of the European Gastrointestinal Motility Society 2012;24(9):844-52.[CrossRef] [PubMed]

21. Blair PJ, Bayguinov Y, Sanders KM, Ward SM. Relationship between enteric neurons and interstitial cells in the primate gastrointestinal tract. Neurogastroenterology and motility: the official journal of the European Gastrointestinal Motility Society 2012;24(9): e437-49.[CrossRef] [PubMed]

22. Koh BH, Roy R, Hollywood MA, Thornbury KD, McHale NG, Sergeant GP, et al. Platelet-derived growth factor receptor-alpha cells in mouse urinary bladder: a new class of interstitial cells. Journal of cellular and molecular medicine 2012;16(4):691-700. [CrossRef] [PubMed]

23. Kurahashi M, Nakano Y, Hennig GW, Ward SM, Sanders KM. Platelet-derived growth factor receptor apositive cells in the tunica muscularis of human colon. Journal of cellular and molecular medicine 2012;16 (7):1397-404.[CrossRef] [PubMed]

24. Monaghan KP, Johnston L, McCloskey KD. Identification of PDGFRalpha positive populations of interstitial cells in human and guinea pig bladders. The Journal of urology2012;188(2):639-47.[CrossRef] [PubMed]

25. Koh SD, Ward SM, Sanders KM. Ionic conductances regulating the excitability of colonic smooth muscles. Neurogastroenterology and motility: the official journal of the European Gastrointestinal Motility Society 2012;24(8):705-18.[CrossRef] [PubMed]

26. Sanders KM, Koh SD, Ro S, Ward SM. Regulation of gastrointestinal motility--insights from smooth muscle biology. Nature reviews Gastroenterology \& hepatology 2012;9(11):633-45.[CrossRef] [PubMed] 
27. Kurahashi M, Zheng $H$, Dwyer L, Ward SM, Koh SD, Sanders KM. A functional role for the 'fibroblast-like cells' in gastrointestinal smooth muscles. The Journal of physiology 2011;589(Pt 3):697-710. [CrossRef] [PubMed]

28. Vanderwinden JM, Rumessen JJ, de Kerchove d'Exaerde A, Jr, Gillard K, Panthier JJ, de Laet $\mathrm{MH}$, et al. Kit-negative fibroblast-like cells expressing SK3, a $\mathrm{Ca}^{2+}$-activated $\mathrm{K}^{+}$channel, in the gut musculature in health and disease. Cell and tissue research 2002;310 (3):349-58. [CrossRef] [PubMed]

29. Klemm MF, Lang RJ. Distribution of Ca2+-activated $\mathrm{K}+$ channel (SK2 and SK3) immunoreactivity in intestinal smooth muscles of the guinea-pig. Clinical and experimental pharmacology \& physiology 2002; 29(1-2):18-25.[CrossRef] [PubMed]

30. Fujita A, Takeuchi T, Jun H, Hata F. Localization of $\mathrm{Ca}^{2+}$-activated $\mathrm{K}^{+}$channel, $\mathrm{SK} 3$, in fibroblast-like cells forming gap junctions with smooth muscle cells in the mouse small intestine. Journal of pharmacological sciences 2003;92(1):35-42. [CrossRef] [PubMed]

31. Horiguchi $\mathrm{K}$, Komuro T. Ultrastructural observations of fibroblast-like cells forming gap junctions in the $\mathrm{W} / \mathrm{W}(\mathrm{nu})$ mouse small intestine. Journal of the autonomic nervous system 2000;80(3):142-7. [CrossRef] [PubMed]

32. Fredriksson L, Li H, Eriksson U. The PDGF family: four gene products form five dimeric isoforms. Cytokine \& growth factor reviews 2004;15(4):197-204. [CrossRef] [PubMed]

33. Hoch RV, Soriano P. Roles of PDGF in animal development. Development (Cambridge, England) 2003;130 (20):4769-84. [CrossRef] [PubMed]

34. Andrae J, Gallini R, Betsholtz C. Role of plateletderived growth factors in physiology and medicine. Genes \& development 2008;22(10):1276-312. [CrossRef] [PubMed]

35. Wallace AS, Burns AJ. Development of the enteric nervous system, smooth muscle and interstitial cells of Cajal in the human gastrointestinal tract. Cell and tissue research 2005;319(3):367-82.

[CrossRef] [PubMed]

36. Chevalier NR, Fleury V, Dufour S, Proux-Gillardeaux V, Asnacios A. Emergence and development of gut motility in the chicken embryo. Plos one 2017;12 (2):e0172511.[CrossRef] [PubMed]

37. Abramovic M, Radenkovic G, Velickov A. Appearance of interstitial cells of Cajal in the human midgut. Cell and tissue research 2014;356(1):9-14. [CrossRef] [PubMed]

38. Radenkovic G. Two patterns of development of interstitial cells of Cajal in the human duodenum. Journal of cellular and molecular medicine 2012;16 (1):185-92.[CrossRef] [PubMed]

39. Radenkovic G, Radenkovic D, Velickov A. Development of interstitial cells of Cajal in the human digestive tract as the result of reciprocal induction of mesenchymal and neural crest cells. Journal of cellular and molecular medicine 2018;22(2):778-85.

[CrossRef] [PubMed]

40. Kurahashi M, Niwa $Y$, Cheng J, Ohsaki $Y$, Fujita A, Goto $\mathrm{H}$, et al. Platelet-derived growth factor signals play critical roles in differentiation of longitudinal smooth muscle cells in mouse embryonic gut. Neurogastroenterology and motility: the official journal of the European Gastrointestinal Motility Society 2008;20(5):521-31.[CrossRef] [PubMed]

41. Soriano P. The PDGF alpha receptor is required for neural crest cell development and for normal patterning of the somites. Development 1997;124(14): 2691-700.[CrossRef] [PubMed]
42. Hamilton TG, Klinghoffer RA, Corrin PD, Soriano P. Evolutionary divergence of platelet-derived growth factor alpha receptor signaling mechanisms. Molecular and cellular biology 2003;23(11):4013-25.

[CrossRef] [PubMed]

43. Kurahashi M, Mutafova-Yambolieva V, Koh SD, Sanders KM. Platelet-derived growth factor receptoralpha-positive cells and not smooth muscle cells mediate purinergic hyperpolarization in murine colonic muscles. American journal of physiology Cell physiology 2014;307(6):C561-70.

[CrossRef] [PubMed]

44. Karlsson L, Lindahl P, Heath JK, Betsholtz C. Abnormal gastrointestinal development in PDGF-A and PDGFR(alpha) deficient mice implicates a novel mesenchymal structure with putative instructive properties in villus morphogenesis. Development 2000;127(16):3457-66. [CrossRef] [PubMed]

45. Walton KD, Kolterud A, Czerwinski MJ, Bell MJ, Prakash A, Kushwaha J, et al. Hedgehog-responsive mesenchymal clusters direct patterning and emergence of intestinal villi. Proceedings of the National Academy of Sciences of the United States of America 2012;109(39):15817-22.[CrossRef] [PubMed]

46. Chan $F$, Liu $Y$, Sun $H$, Li $X$, Shang $H$, Fan $D$, et al. Distribution and possible role of PDGF-AA and PDGFRalpha in the gastrointestinal tract of adult guinea pigs. Virchows Archiv : an international journal of pathology 2010;457(3):381-8.[CrossRef] [PubMed]

47. Kurahashi M, Nakano Y, Peri LE, Townsend JB, Ward SM, Sanders KM. A novel population of subepithelial platelet-derived growth factor receptor a-positive cells in the mouse and human colon. American journal of physiology Gastrointestinal and liver physiology 2013; 304(9):G823-G34. [CrossRef] [PubMed]

48. Faussone-Pellegrini MS, Cortesini C, Romagnoli P. The ultrastructure of the muscle coat of human gastrooesophageal junction, with special reference to "interstitial cells of Cajal". Frontiers in Neuroscience 2013; 7:49.[CrossRef] [PubMed]

49. Gomez-Pinilla PJ, Gibbons SJ, Bardsley MR, Lorincz A, Pozo MJ, Pasricha PJ, et al. Ano1 is a selective marker of interstitial cells of Cajal in the human and mouse gastrointestinal tract. American journal of physiology Gastrointestinal and liver physiology 2009;296(6): G1370-81.[CrossRef] [PubMed]

50. Hwang SJ, Blair PJ, Britton FC, O'Driscoll KE, Hennig $G$, Bayguinov $Y R$, et al. Expression of anoctamin $1 /$ TMEM16A by interstitial cells of Cajal is fundamental for slow wave activity in gastrointestinal muscles. The Journal of physiology 2009;587(Pt 20):4887-904. [CrossRef] [PubMed]

51. Sanders KM, Salter AK, Hennig GW, Koh SD, Perrino BA, Ward SM, et al. Responses to enteric motor neurons in the gastric fundus of mice with reduced intramuscular interstitial cells of cajal. Journal of neurogastroenterology and motility 2014;20(2):17184.[CrossRef] [PubMed]

52. Cobine CA, Hennig GW, Kurahashi M, Sanders KM, Ward SM, Keef KD. Relationship between interstitial cells of Cajal, fibroblast-like cells and inhibitory motor nerves in the internal anal sphincter. Cell and tissue research 2011;344(1):17-30.[CrossRef] [PubMed]

53. Olson LE, Soriano P. Increased PDGFRalpha activation disrupts connective tissue development and drives systemic fibrosis. Developmental cell 2009;16(2):30313.[CrossRef] [PubMed]

54. Wang Q, Zang J, Huang X, Lu H, Xu W, Chen J. Colonic Dysmotility in Murine Partial Colonic Obstruction Due to Functional Changes in Interstitial Cells. Journal of neurogastroenterology and motility 2019;25(4):589-601.[CrossRef] [PubMed] 
55. Joensuu H. Gastrointestinal stromal tumor (GIST). Annals of oncology: official journal of the European Society for Medical Oncology 2006; 17(10):x280-6. [CrossRef] [PubMed]

56. Hirota $S$, Ohashi A, Nishida T, Isozaki K, Kinoshita $K$, Shinomura Y, et al. Gain-of-function mutations of platelet-derived growth factor receptor alpha gene in gastrointestinal stromal tumors. Gastroenterology 2003;125(3):660-7.[CrossRef] [PubMed]

\title{
DISTRIBUCIJA PDGFR $\alpha+$ ĆELIJA I INTERSTICIJALNIH ĆELIJA KAHALA U CREVU FETUSA ČOVEKA
}

\author{
Goran Radenković ${ }^{1}$, Aleksandra Veličkov ${ }^{1}$, Vladimir Petrović1 ${ }^{1}$ Miloš Dičić ${ }^{2}$, Marko Gmijović
}

\author{
${ }^{1}$ Univerzitet u Nišu, Medicinski fakultet, Katedra za histologiju i embriologiju, Niš, Srbija \\ Univerzitet u Nišu, Medicinski fakultet, Niš, Srbija \\ ${ }^{3}$ Klinika za digestivnu hirurgiju, Klinički centar Niš, Niš, Srbija \\ Kontakt: Goran Radenković \\ Bulevar dr Zoran Đinđić 81, 18000 Niš, Srbija \\ E-mail: goran.radenkovic@medfak.ni.ac.rs
}

Unutar mišićnog sloja gastrointestinalnog (GI) trakta prisutna su dva tipa intersticijalnih ćelija: Intersticijalne ćelije Kahala (IĆK) i "fibroblastima-slične" ćelije, nedavno nazvane receptor za trombocitni faktora rasta pozitivne (PDGFR $\alpha+$ ) ćelije. IĆK i PDGFR $\alpha+$ ćelije predstavljaju različite ćelijske klase jedinstvene ultrastrukture i funkcije i zauzimaju iste anatomske niše u GI traktu. Smatra se da PDGFR $\alpha+$ ćelije, kao i IĆK, učestvuju u modulaciji inhibitorne neurotransmisije. Trombocitni faktor rasta (PDGF) glavni je mitogen za mnoge ćelije mezenhimalnog porekla, kao što su fibroblasti i glatko mišićne ćelije, te je PDGF signalizacija neophodna tokom organogeneze.

Cilj rada je da identifikuje PDGFR $\alpha$ imunoreaktivne ćelije u crevima fetusa čoveka, kao i da odredi njihovu distribuciju u odnosu na glatko mišićne ćelije, IĆK i strukture enteričkog sistema.

Materijal je činilo 12 humanih fetusa, gestacione starosti od 10. do 12 . nedelje. Imunohistohemijsko ispitivanje vršeno je PDGFR $\alpha$ antitelom, IĆK identifikovane su pomoću C-kit antitela, dok su mišićne strukture dokazane desmin antitelom.

PDGFR $\alpha$ imunoreaktivne ćelije prisutne su unutar kružnog mišićnog sloja, dok su odsutne u regionu mijenteričnog pleksusa i u delovima ispod seroze. Za razliku od njih, IĆK prisutne su samo oko začetaka gangliona mijenteričnog pleksusa.

U fetusnom periodu razvića čoveka, PDGFR $\alpha$ imunoreaktivne ćelije prisutne su u svim delovima creva, lokalizovane su unutar kružnog mišićnog sloja i ne podudaraju se sa IĆK.

Acta Medica Medianae 2020;59(1):51-59.

KIjučne reči: PDGFR $\alpha, C-k i t$, intersticijalne ćelije Kahala, gastrointestinalni trakt fetusa 